\title{
Excretion and Metabolism of Catecholamines by the Isolated Perfused Rat Kidney
}

\author{
Patricio Silva, Lewis Landsberg, and Anatole Besarab, Department of \\ Medicine and the Thorndike Laboratory of Harvard Medical School at \\ Beth Israel Hospital, Boston, Massachusetts 02215
}

\begin{abstract}
A B S TRACT The excretion and metabolism of labeled epinephrine and norepinephrine by the isolated, perfused rat kidney were studied. The excretion of both catecholamines significantly exceeded the amount filtered, thus providing direct evidence of net tubular secretion. Renal clearance of epinephrine was significantly greater than that of norepinephrine. Tubular secretion was a linear function of the concentration of unbound catecholamine in the medium with no demonstrable tubular maximum at the concentrations studied. The isolated kidney removed catecholamines from the medium by metabolism as well as excretion in the urine. $O$-Methylation was the major metabolic route and $O$-methylated metabolites were rapidly excreted and concentrated in urine. Preferential excretion and metabolism of epinephrine were confirmed in double-label experiments in which $\left[{ }^{14} \mathrm{C}\right]$ epinephrine and $\left[{ }^{3} \mathrm{H}\right]$ norepinephrine were perfused together. The ratio of ${ }^{14} \mathrm{C}:{ }^{3} \mathrm{H}$ in urine exceeded that in perfusion medium for total radioactivity as well as for catecholamines and $O$-methylated amines.
\end{abstract}

The present study thus provides direct evidence for (a) net tubular secretion of epinephrine and norepinephrine with a direct relationship between secretion and medium concentration; $(b)$ significant renal metabolism of both epinephrine and norepinephrine with $O$-methylation as the major metabolic route; and (c) preferential excretion and metabolism of epinephrine.

\section{INTRODUCTION}

The mechanisms involved in catecholamine clearance and excretion by the kidney are poorly understood (1). Definite evidence of tubular secretion of various cate-

Presented before the American Federation for Clinical Research, Atlantic City, N. J., May 1976. This work appeared in abstract form in 1976. Clin. Res. 24: 258.

Dr. Silva is an Established Investigator of the American Heart Association.

Received for publication 9 January 1979 and in revised form 18 May 1979. cholamines (including epinephrine and norepinephrine) has been obtained in chickens using the Sperber technique (2-4). In mammals, conflicting data have been reported, some supporting $(5,6)$ and some opposing net tubular secretion of catecholamines (7). Similarly, the metabolism of catecholamines by the kidney has not been well described. Mammalian kidney possesses monoamine oxidase and catechol-O-methyl transferase (8), the enzymes responsible for the major metabolic transformations of epinephrine and norepinephrine. Mammalian urine contains $O$-methylated and deaminated catecholamine metabolites. The chicken kidney is capable of forming some of these compounds (9), but the extent to which the kidney contributes to the overall metabolism of catecholamines and to the production of catecholamine metabolites that appear in urine, is unknown.

Studies of renal catecholamine clearance in intact mammals including man have been limited because of the difficulty of accurately measuring catecholamines in plasma, coupled with the short half-life of plasma catecholamines ( $<1 \mathrm{~min})(10)$, and the lability of endogenous catecholamine production and release. Studies based on infusions of tracer epinephrine $(E)^{1}$ and norepinephrine (NE) are confounded by neuronal uptake and extraneuronal metabolism, as well as the hemodynamic alterations induced by infusion of these potent catecholamines.

The isolated perfused rat kidney circumvents some of these problems. This preparation $(11,12)$, which involves the continuous recirculation of $\cong 70 \mathrm{ml}$ of an artificial cell-free medium, has a glomerular filtration rate approaching that found in anesthetized intact rats, and reabsorbs $>94 \%$ of filtered sodium (13). The preparation is stable for $60-90 \mathrm{~min}$, and the medium can be sampled repeatedly as the urine is collected. In the present study, labeled $\mathrm{E}$ and $\mathrm{NE}$ were added

\footnotetext{
${ }^{1}$ Abbreviations used in this paper: E, epinephrine; GFR, glomerular filtration rate; NE, norepinephrine; VMA, vanillylmandelic acid.
} 
to the perfusion medium, and the medium and urine analyzed for catecholamines and catecholamine metabolites. The results indicate net tubular secretion of both $\mathrm{E}$ and $\mathrm{NE}$, and significant metabolism to $O$-methylated derivatives. Both the rate of secretion and the rate of metabolism were significantly greater for $\mathrm{E}$ than for NE.

\section{METHODS}

Isolated perfused rat kidney preparation. Male SpragueDawley rats weighing from 240 to $490 \mathrm{~g}$ were used for all experiments. The rats were fed Purina Rat Chow (Ralston Purina Co., St. Louis, Mo.) and allowed free access to water. Perfusion of the right kidney was performed according to the technique of Nishiitsutsuji-Uwo et al. (11) as modified by Ross et al. (12). The animals were anesthetized with pentobarbital $(60 \mathrm{mg} / \mathrm{kg}$ i.p.); mannitol $(50 \mathrm{mg} / 100 \mathrm{~g})$ and heparin (1,000 U) were injected into the femoral vein. The peritoneal cavity was opened, and polyethylene catheters placed in the right ureter and the inferior vena cava. A glass cannula was inserted into the superior mesenteric artery and threaded across the aorta into the right renal artery. Perfusion was started while the glass cannula was still in the mesenteric artery. Perfusion medium was recirculated continuously with pulsatile flow at a pressure of 100/80 $\mathrm{mm} \mathrm{Hg}$ distal to the tip of the arterial cannula. The kidneys were perfused inside a cabinet kept at a temperature of $37^{\circ} \mathrm{C}$. The perfusion medium contained (millimoles): sodium 140, potassium 5 , calcium 2.5, magnesium 1.2 , bicarbonate 25 , chloride 120 , phosphate 1.2 , and sulfate 0.8 . The $\mathrm{pH}$ was 7.4 when gassed with $5 \% \mathrm{CO}_{2}$ and $95 \% \mathrm{O}_{2}$. The medium was initially prepared as a $10-\mathrm{g} / 100-\mathrm{ml}$ solution of albumin (bovine albumin, fraction V, Pentex, Miles Laboratory, Elkhart, Ind.) and diluted to a final concentration of $6.7-7.0 \mathrm{~g} / 100 \mathrm{ml}$ with a solution of identical ionic composition. Glucose $(5 \mathrm{mM})$ was the sole exogenous substrate in all the experiments. Glomerular filtration rate was determined by inulin clearance. Inulin concentration was determined chemically on the medium and the urine (14).

Radioisotopes and counting techniques. $\mathrm{L}-\left[7-{ }^{3} \mathrm{H}\right] \mathrm{NE}$, D,L-[7- $\left.{ }^{3} \mathrm{H}\right] \mathrm{NE}, \mathrm{D}, \mathrm{L}-\left[7-{ }^{3} \mathrm{H}\right] \mathrm{E}(3-12 \mathrm{Ci} / \mathrm{mmol})$, and $\mathrm{D}, \mathrm{L}-\left[{ }^{14} \mathrm{C}\right] \mathrm{E}$ $(50 \mathrm{mCi} / \mathrm{mmol})$ were obtained from New England Nuclear (Boston, Mass.). They were purified before use by column chromatography on alumina. Corresponding nonradioactive compounds were obtained from Calbiochem (San Diego, Cal.) or Sigma Chemical Co. (St. Louis, Mo.) and also chromatographically purified.

200 liters of aqueous sample were mixed with $4.0 \mathrm{ml}$ of ethanol/methanol $(3: 1)$ and $10 \mathrm{ml}$ of toluene Liquifluor (New England Nuclear). Radioactivity was determined by liquid scintillation spectrometry in a 3-channel scintillation counter (Nuclear Chicago Corp., Des Plaines, Ill.), at an efficiency for ${ }^{3} \mathrm{H}$ of $8-10 \%$. All samples were counted to at least 10 times the background in counts per minute to reduce the statistical error of counting. In the double-label experiments, the window and gain were adjusted so that less than $1 \%$ of ${ }^{3} \mathrm{H}$ counts were detected in the ${ }^{14} \mathrm{C}$ channel.

Chromatographic separation of $\left[{ }^{3} \mathrm{H}\right]$ catecholamines and metabolites. Aliquots of perfusion medium, urine, or kidney were mixed with (or homogenized in) $0.4 \mathrm{~N} \mathrm{HClO}_{4}$ and the precipitated protein removed by centrifugation. The $\left[{ }^{3} \mathrm{H}\right]-$ metabolites in the perchloric acid extract were separated chromatographically using alumina and Dowex (Bio-Rad Laboratories, Richmond, Calif.) columns (15). The alumina (Woelm Neutral-Waters Associates Inc., Millford, Mass.) was purified before use according to the method of Anton and Sayre (16); Dowex (50 W × 4, 100-200 mesh, Bio-Rad Labora- tories) was prepared according to the method of Hirs et al. (17). Chromatographic columns (Kontes Co., Vineland, N. J.) with an internal diameter of $5 \mathrm{~mm}$ were used. Adsorption of catecholamines on alumina at $\mathrm{pH} 8.6$ was performed as previously described (15). Results were corrected for recovery of $\left[{ }^{3} \mathrm{H}\right] \mathrm{NE}$ or $\left[{ }^{3} \mathrm{H}\right] \mathrm{E}$ as determined in each experiment (average $90 \%$, $<10 \%$ variation between columns). Catechol acids were extracted from the alumina eluate into ethyl acetate at $\mathrm{pH} 1$, after saturation with sodium chloride (18). Contamination of the catechol acid fraction by $\left[{ }^{3} \mathrm{H}\right]$ catecholamine was $<0.2 \%$ and appropriate correction was made in each experiment. The alumina effluent, which contains the noncatecholamine metabolites, was adjusted to $\mathrm{pH} 2$ and passed over Dowex (5). The $\mathrm{O}$-methylated amines (normetanephrine and metanephrine) were adsorbed on Dowex and eluted with $3 \mathrm{~N} \mathrm{HCl}$ in $50 \%$ ethanol (19). Values were corrected for a recovery of $85-90 \%$, and a contamination of $2-4 \%$ by $\left[{ }^{3} \mathrm{H}\right]$ catecholamine as determined in each experiment. $O$-methylated-deaminated metabolites (vanillyl-mandelic acid, VMA) were calculated by difference. In some experiments an aliquot of urine was incubated at pH 5.4 with Glusulase (Endo Laboratories, Inc., Garden City, N. Y.), a crude enzyme preparation containing glucuronidase and sulfatase activity, for $18 \mathrm{~h}$ at $37^{\circ} \mathrm{C}$ as described previously $(15,20)$. Control aliquots were incubated without enzyme. After incubation, these samples were analyzed chromatographically in the same manner as nonincubated urine aliquots.

Binding of $\left[{ }^{3} \mathrm{H}\right]$ catecholamines to albumin in the perfusion medium. Binding of $\mathrm{L}-\left[{ }^{3} \mathrm{H}\right] \mathrm{NE}, \mathrm{D}, \mathrm{L}-\left[{ }^{3} \mathrm{H}\right] \mathrm{NE}, \mathrm{D}, \mathrm{L}-\left[{ }^{3} \mathrm{H}\right] \mathrm{E}$, and $\mathrm{D}, \mathrm{L}-\left[{ }^{14} \mathrm{C}\right] \mathrm{E}$ to the albumin in the perfusate was measured using the method described by Toribara (21). Binding of the catecholamines was determined separately for each perfusion experiment and the value for the measured bound and unbound fractions used to calculate the excretion of these hormones. For the actual measurement, a sample of the perfusate to be used in each perfusion was separated from the initial perfusion medium and enough catecholamines were added to achieve the same concentration as that used in the experiment. The samples were placed in cellophane bags, placed in Toribara centrifuge tubes, kept at $37^{\circ} \mathrm{C}$ and gassed for $30 \mathrm{~min}$ with the same gas mixture of $95 \% \mathrm{O}_{2}$ and $5 \% \mathrm{CO}_{2}$ used in the perfusion. Samples were then spun at a constant temperature of $37^{\circ} \mathrm{C}$ until $\cong 10 \%$ of the initial volume was filtered. The average binding for $\mathrm{L}-\left[{ }^{3} \mathrm{H}\right] \mathrm{NE}$ was $70.2 \pm 2.1 \%(n=19)$, for $\mathrm{D}, \mathrm{L}-\left[{ }^{3} \mathrm{H}\right] \mathrm{NE}$ was $68.9 \pm 2.6 \%(n=12)$, and that for $\mathrm{D}, \mathrm{L}-\left[{ }^{3} \mathrm{H}\right] \mathrm{E}$ and $\mathrm{D}, \mathrm{L}-$ $\left[{ }^{14} \mathrm{C}\right] \mathrm{E} 63.8 \pm 1.3 \%(n=12)$. These values compare well with those published in the literature on man (23-25), dog (6), and chicken (6). With albumin absent from the solution, the catecholamines did not bind to the membrane and their recovery in the ultrafiltrate was $100 \%$.

Catecholamine clearance and metabolism. Catecholamine clearance was determined from the concentration of labeled $\mathrm{E}$ and $\mathrm{NE}$ in the perfusion medium and the urine. In separate perfusions, L- $\left[{ }^{3} \mathrm{H}\right] \mathrm{NE}, \mathrm{D}, \mathrm{L}-\left[{ }^{3} \mathrm{H}\right] \mathrm{NE}, \mathrm{D}, \mathrm{L}-\left[{ }^{3} \mathrm{H}\right] \mathrm{E}$ were added to the medium after $30 \mathrm{~min}$ of perfusion with medium alone. The naturally occurring $\mathrm{L}$-isomer of $\mathrm{E}$ was not available in labeled form. Studies were therefore performed with D,L- $\left[{ }^{3} \mathrm{H}\right] \mathrm{NE}$ as well as $L-\left[{ }^{3} \mathrm{H}\right] \mathrm{NE}$ for better comparison with racemic $\mathrm{E}$. The initial medium concentration of total catecholamine was varied between 3 and $30 \mathrm{ng} / \mathrm{ml}$ in different experiments. Samples of perfusion medium and urine were collected every 5-10 min and analyzed for $\left[{ }^{3} \mathrm{H}\right]$ catecholamines, $\left[{ }^{3} \mathrm{H}\right]$ catecholamine metabolites, and inulin.

Calculations and statistical analyses. Calculations and statistical analyses were performed with the aid of the computer facilities of the Harvard Clinical Research Center at Beth Israel Hospital (Prophet System). Clearances were calculated from standard formulas. Results are expressed as the mean $\pm S D$. 


\section{RESULTS}

Clearance and fractional excretion of $N E$ and $E$. The clearance of $\mathrm{L}-\left[{ }^{3} \mathrm{H}\right] \mathrm{NE}, \mathrm{D}, \mathrm{L}-\left[{ }^{3} \mathrm{H}\right] \mathrm{NE}$, and $\mathrm{D}, \mathrm{L}-\left[{ }^{3} \mathrm{H}\right] \mathrm{E}$ rose rapidly after the addition of the catecholamines to the perfusate and reached a peak 15-20 min later. The pooled values for all the clearance periods after the peak are shown in Table I. The clearance of $L-\left[{ }^{3} \mathrm{H}\right] \mathrm{NE}$ was a remarkably constant fraction of the glomerular filtration rate (GFR), 61 and $66 \%$ at 21.6 and $3.3 \mathrm{ng} / \mathrm{ml}$ of catecholamine in the perfusate, respectively. Initial plasma concentrations of $\mathrm{L}-\left[{ }^{3} \mathrm{H}\right] \mathrm{NE}$ were $26.1 \pm 6.9$ (6) and $5.7 \pm 1.5(9)$; for $\mathrm{D}, \mathrm{L}-\left[{ }^{3} \mathrm{H}\right] \mathrm{NE}, 6.9 \pm 3.3$ (12); for $\mathrm{D}, \mathrm{L}-\left[{ }^{3} \mathrm{H}\right] \mathrm{E}, 6.7 \pm 1.3(6)$. The clearance of $\mathrm{D}, \mathrm{L}-\left[{ }^{3} \mathrm{H}\right] \mathrm{NE}$ was somewhat larger than that of $L-\left[{ }^{3} \mathrm{H}\right] \mathrm{NE}, 122 \%$ of the GFR. The clearance of $\mathrm{D}, \mathrm{L}-\left[{ }^{3} \mathrm{H}\right] \mathrm{E}$ was $281 \%$ of the GFR, significantly larger than that of either L- or D,L- $\left[{ }^{3} \mathrm{H}\right] \mathrm{NE}$. Because only a fraction of the cate- cholamines are found free in the recirculating medium, as a result of their binding to the albumin in the perfusate, their clearance was recalculated using the free, unbound fraction of catecholamines as a true expression of their concentration in the perfusate. The clearance of unbound catecholamines was consistently higher than GFR ranging from 294 to $362 \%$ of GFR for L- and $\mathrm{D}, \mathrm{L}-\left[{ }^{3} \mathrm{H}\right] \mathrm{NE}$, and $730 \%$ for $\mathrm{D}, \mathrm{L}-\left[{ }^{3} \mathrm{H}\right] \mathrm{E}$. There was thus a clear difference between the pooled values for the fractional excretion of L- and $D, L-\left[{ }^{3} \mathrm{H}\right] \mathrm{NE}$ and those of $D, L-\left[{ }^{3} \mathrm{H}\right] \mathrm{E}$.

Fig. 1 clarifies the relation between the clearance of unbound catecholamines and GFR. It can be seen that the clearances of both $\mathrm{D}, \mathrm{L}-\left[{ }^{3} \mathrm{H}\right] \mathrm{E}$ and $\mathrm{L}$ - and $\mathrm{D}, \mathrm{L}$ $\left[{ }^{3} \mathrm{H}\right] \mathrm{NE}$ increase as GFR increases. The clearance of $D, L-\left[{ }^{3} \mathrm{H}\right] E$ is markedly different from that of $L$ - or $D, L-\left[{ }^{3} \mathrm{H}\right] \mathrm{NE}$ as evidenced by the different slopes of their regression lines, 2.91 and 2.39 for $L-$ and $D, L-\left[{ }^{3} \mathrm{H}\right] \mathrm{NE}$,

TABLE I

Excretion of Catecholamines in Isolated Perfused Rat Kidneys

\begin{tabular}{|c|c|c|c|c|c|c|}
\hline \multirow[b]{2}{*}{$\mathrm{V}, \mathrm{ml} / \mathrm{min}$} & \multirow{2}{*}{$\begin{array}{c}\mathrm{L}-\left[^{3} \mathrm{H}\right] \mathrm{NE} \\
\begin{array}{c}0.071 \pm 0.028 \\
(80)\end{array}\end{array}$} & \multicolumn{2}{|c|}{ D,L- $\left[{ }^{3} \mathrm{H}\right] \mathrm{NE}$} & \multicolumn{3}{|c|}{ D,L-L $\left[{ }^{3} \mathrm{H}\right] \mathrm{E}$} \\
\hline & & $\begin{array}{c}0.084 \pm 0.045 \\
(37)\end{array}$ & NS* & $\begin{array}{c}0.049 \pm 0.027 \\
(19)\end{array}$ & $<0.01^{*}$ & $<0.01 \downarrow$ \\
\hline $\mathrm{P}_{\text {cat }}, n g / m l$ & $\begin{array}{c}10.55 \pm 9.81 \\
(86)\end{array}$ & $\begin{array}{l}4.5 \pm 1.90 \\
(37)\end{array}$ & $<0.01$ & $\begin{array}{c}3.8 \pm 1.44 \\
(19)\end{array}$ & $<0.01$ & $<0.01$ \\
\hline $\mathrm{U}_{\text {cat }}, n g / m l$ & $\begin{array}{c}44.2 \pm 43.3 \\
(86)\end{array}$ & $\begin{array}{c}67.7 \pm 58.3 \\
(37)\end{array}$ & $<0.05$ & $\begin{array}{c}150.6 \pm 116.7 \\
(19)\end{array}$ & $<0.01$ & $<0.01$ \\
\hline $\mathrm{C}_{\text {cat }}, \mathrm{ml} / \mathrm{min}$ & $\begin{array}{c}0.42 \pm 0.25 \\
(68)\end{array}$ & $\begin{array}{c}0.78 \pm 0.24 \\
(37)\end{array}$ & $<0.01$ & $\begin{array}{c}1.88 \pm 1.03 \\
(19)\end{array}$ & $<0.01$ & $<0.01$ \\
\hline $\mathrm{C}_{\mathrm{Fcat}}, \mathrm{ml} / \mathrm{min}$ & $\begin{array}{c}1.92 \pm 1.15 \\
(68)\end{array}$ & $\begin{array}{c}2.58 \pm 1.04 \\
(37)\end{array}$ & $<0.01$ & $\begin{array}{c}4.53 \pm 2.49 \\
(19)\end{array}$ & $<0.01$ & $<0.01$ \\
\hline $\mathrm{GFR}, \mathrm{ml} / \mathrm{min}$ & $\begin{array}{c}0.66 \pm 0.37 \\
(78)\end{array}$ & $\begin{array}{c}0.73 \pm 0.26 \\
(37)\end{array}$ & NS & $\begin{array}{c}0.62 \pm 0.11 \\
(19)\end{array}$ & NS & $<0.05$ \\
\hline $\mathrm{FE}_{\text {cat }}$ & $\begin{array}{c}0.64 \pm 0.20 \\
(68)\end{array}$ & $\begin{array}{c}1.22 \pm 0.55 \\
(37)\end{array}$ & $<0.01$ & $\begin{array}{c}2.81 \pm 2.40 \\
(19)\end{array}$ & $<0.01$ & $<0.01$ \\
\hline $\mathrm{FE}_{\mathrm{Fcat}}$ & $\begin{array}{c}2.94 \pm 0.90 \\
(68)\end{array}$ & $\begin{array}{c}3.62 \pm 0.80 \\
(37)\end{array}$ & $<0.01$ & $\begin{array}{l}7.3 \pm 5.78 \\
(19)\end{array}$ & $<0.01$ & $<0.01$ \\
\hline Tubular secretion, $n g / m i n$ & $\begin{array}{c}2.14 \pm 2.24 \\
(68)\end{array}$ & $\begin{array}{c}2.69 \pm 1.66 \\
(37)\end{array}$ & NS & $\begin{array}{c}5.67 \pm 3.87 \\
(19)\end{array}$ & $<0.01$ & $<0.01$ \\
\hline
\end{tabular}

Summary of all values for catecholamine excretion in all collection periods (figures in parentheses) after steady-state excretion was achieved. Total number of experiments for $L-\left[{ }^{3} \mathrm{H}\right] \mathrm{NE}=15$, for $\mathrm{D}, \mathrm{L}-\left[{ }^{3} \mathrm{H}\right] \mathrm{NE}=12$, for $\mathrm{D}, \mathrm{L}-\left[{ }^{3} \mathrm{H}\right] \mathrm{E}=6$. The concentration of catecholamines in the perfusate ranged (in nanograms per milliliter) from 0.63 to 35.78 for $\mathrm{L}-\left[{ }^{3} \mathrm{H}\right] \mathrm{NE}, 1.96$ to 10.38 for $\mathrm{D}, \mathrm{L}-\left[{ }^{3} \mathrm{H}\right] \mathrm{NE}$, and 1.0 to 6.38 for $\mathrm{D}, \mathrm{L}-\left[{ }^{3} \mathrm{H}\right] \mathrm{E}$. Urinary collection periods were $5-10$ min in duration and at least three successive 10-min or six 5-min collection periods for each experiment are summarized here. Perfusate concentrations of catecholamines were measured both at the mid and end point of the collection period. Calculation of free or unbound excretion of catecholamines was done using the percentage bound as described in Methods. The average rate of perfusate flow in all experiments at $100 / 80 \mathrm{~mm} \mathrm{Hg}$ of perfusion was $31.7 \pm 4.9(35)$, the flows for the experiments at high concentrations of norepinephrine $(10 \mathrm{ng} / \mathrm{ml})$ was $26 \pm 2.9$ (7). Values are mean \pm SD. CAT, catecholamine, FCAT, free (unbound) catecholamine.

* $P$ value as compared with $L-\left[{ }^{3} \mathrm{H}\right] \mathrm{NE}$.

$\$ P$ value as compared with $D, \mathrm{~L}-\left[{ }^{3} \mathrm{H}\right] \mathrm{NE}$. 


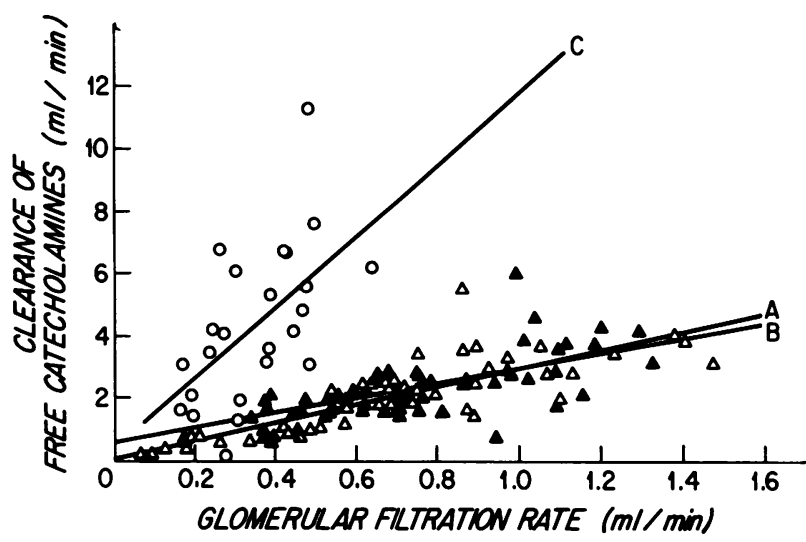

FIGURE 1 Catecholamine clearance as a function of GFR. The clearance of catecholamine was calculated for individual clearance periods of 5- to 10 -min duration after equilibration (from 15 to $50 \mathrm{~min}$ after addition of $\left[{ }^{3} \mathrm{H}\right]$ catecholamine) and correlated with the simultaneously determined inulin clearance. 68 points for $\mathrm{L}-\left[{ }^{3} \mathrm{H}\right] \mathrm{NE}(\triangle$, line $A), 48$ points for $\mathrm{D}, \mathrm{L}-\left[{ }^{3} \mathrm{H}\right] \mathrm{NE}$ $(\triangle$, line $B)$, and 24 points for $D, L-\left[{ }^{3} \mathrm{H}\right] E(O$, line $C)$ were analyzed. Significant linear correlations for catecholamines were found as shown by the correlation coefficients of 0.84 , 0.62 , and 0.58 , respectively, all $P<0.01$. The slope for $\mathrm{L}-\left[{ }^{3} \mathrm{H}\right] \mathrm{NE}$ was $2.91 \pm 0.23$, for $\mathrm{D}, \mathrm{L}-\left[{ }^{3} \mathrm{H}\right] \mathrm{NE} 2.39 \pm 0.44$, and for D,L- $\left[{ }^{3} \mathrm{H}\right] \mathrm{E} 11.66 \pm 3.52$.

and 11.66 for $\mathrm{D}, \mathrm{L}-\left[{ }^{3} \mathrm{H}\right] \mathrm{E}$. This graph shows that both NE and $\mathrm{E}$ are secreted by the kidney and that $\mathrm{E}$ is secreted preferentially over NE.

Secretion of catecholamines. The rate of tubular secretion of catecholamines calculated from standard

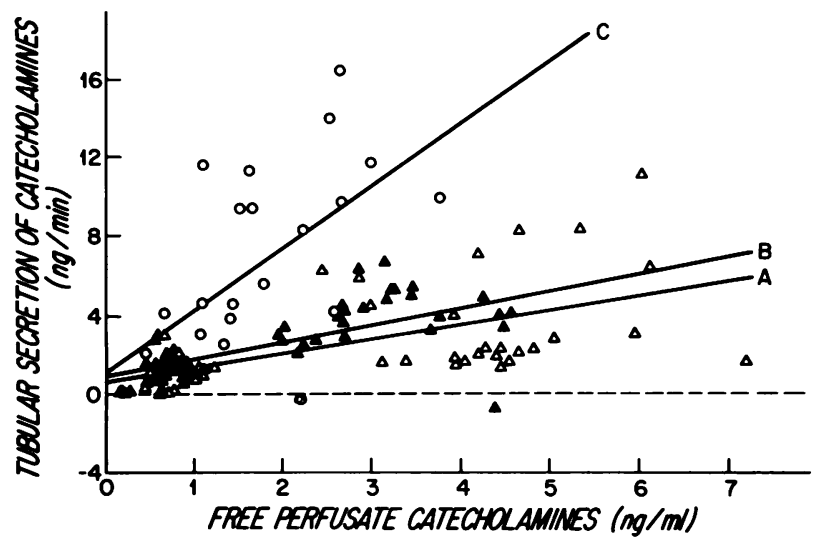

FIgURE 2 Catecholamine secretion as a function of free medium catecholamine level. Tubular secretion in nanograms per minute is plotted against the free catecholamine concentration in the perfusate for individual clearance periods of 5 to $10-\mathrm{min}$ duration after equilibration (15-50 min after addition of $\left[{ }^{3} \mathrm{H}\right]$ catecholamine). Linear correlations were obtained for each catecholamine. No tubular maximum for either $\mathrm{NE}$ or $\mathrm{E}$ was found over the range of concentrations studied. The slope for $\mathrm{D}, \mathrm{L}-\left[{ }^{3} \mathrm{H}\right] \mathrm{E}$ was significantly greater than the slope for $L-\left[{ }^{3} \mathrm{H}\right] N E$ or $D, L-\left[{ }^{3} \mathrm{H}\right](P<0.01)$. The points for $D, L-\left[{ }^{3} \mathrm{H}\right] N E$ clustered together with the L- $\left[{ }^{3} \mathrm{H}\right] \mathrm{NE}$ points. Symbols as in Fig. 1.

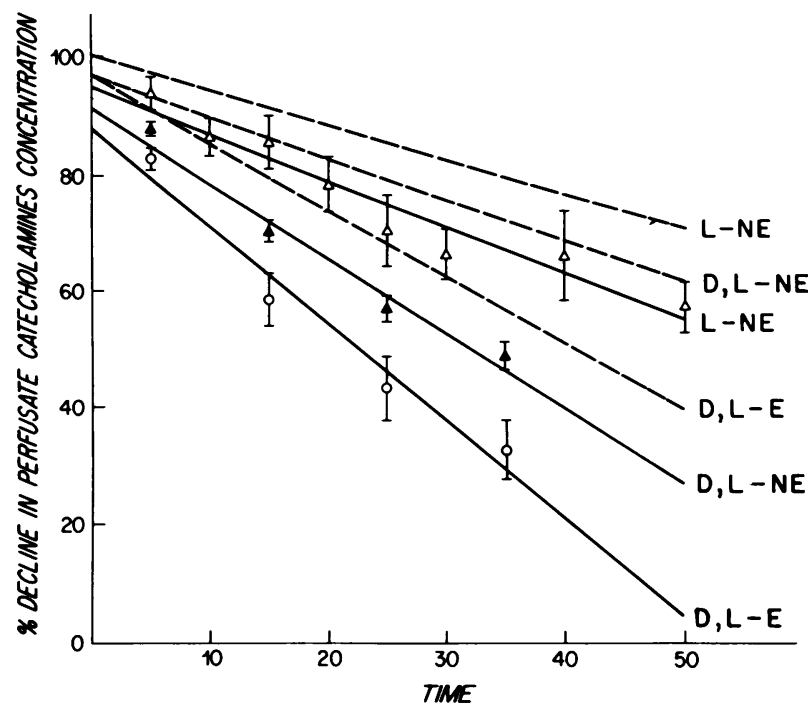

FIgURE 3 Rate of disappearance of $\left[{ }^{3} \mathrm{H}\right]$ catecholamines from the perfusion medium. Time (minutes) is on the horizontal axis; on the vertical axis is the concentration at various times after the addition of $\left[{ }^{3} \mathrm{H}\right]$ catecholamine as a function of the initial concentration. Values are means \pm SEM plotted according to the method of least squares. Note that the fall is monoexponential with a $t_{1 / 2}$ of $26 \mathrm{~min}$ for $E$ and $60 \mathrm{~min}$ for $\mathrm{NE}$. The dotted lines represent the theoretical rate of disappearance for $\mathrm{NE}$ and $\mathrm{E}$ if total catecholamine clearance resulted from excretion in urine. The predicted $t_{1 / 2}$ for $\mathrm{NE}$ is $85 \mathrm{~min}$ and for $\mathrm{E}, \mathbf{4 3} \mathrm{min}$.

formulas for those periods after the peak clearance of catecholamines was reached is shown in Table $I$. As was the case for the clearance and fractional excretion data, the tubular secretion of $D, L-\left[{ }^{3} \mathrm{H}\right] E$ was substantially larger than that of $D, L-$ or $L-\left[{ }^{3} \mathrm{H}\right] \mathrm{NE}$. When the rate of tubular secretion is plotted against the perfusate concentration of free compounds (Fig. 2), it can be observed that at any given perfusate concentration, more $\mathrm{E}$ is excreted than either L- or $\mathrm{D}, \mathrm{L}-\left[{ }^{3} \mathrm{H}\right] \mathrm{NE}$. No difference was observed between L- and D,L- $\left[{ }^{3} \mathrm{H}\right] \mathrm{NE}$.

Metabolism of catecholamines by the isolated kidney. Both NE and $\mathrm{E}$ disappeared from the perfusion medium more rapidly than predicted from their urinary excretion. In Fig. 3, the actual and predicted rate of disappearance is shown as a function of the initial concentrations of L- and D,L- $\left[{ }^{3} \mathrm{H}\right] N E$ and $D, L-\left[{ }^{3} \mathrm{H}\right] E$. It should be noted that between 15 and $40 \mathrm{~min}$ there was no net accumulation or release of ${ }^{3} \mathrm{H}$ by the kidney, indicating that a steady state had been obtained with regard to ${ }^{3} \mathrm{H}$ influx and efflux; furthermore, by $15 \mathrm{~min}$ the fractional excretion of each catecholamine had plateaued, indicating that a stable rate of clearance had been achieved.

The observed decline of both catecholamines from the perfusion medium was monoexponential. The predicted removal rate, based on urinary excretion alone, was considerably slower than the observed rate of removal, thus indicating substantial metabolism by the 


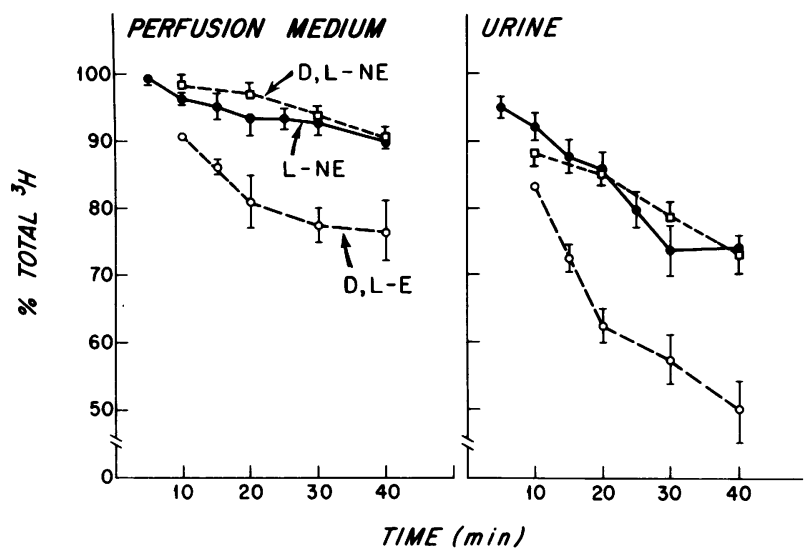

Figure 4 Catecholamines as percent total tritium in urine and plasma. $\left[{ }^{3} \mathrm{H}\right] \mathrm{Catecholamine}$ was added at time zero, and the percent of total tritium due to unmetabolized catecholamine plotted as a function of time for plasma and urine. The percent of unchanged catecholamine decreased progressively and was greater for $\mathrm{NE}$ than $\mathrm{E}$ and greater in medium than in urine. This change reflects progressive metabolic transformation of both hormones with concentration of metabolites in urine. The data were derived from 14 perfusions with $L-\left[{ }^{3} \mathrm{H}\right] \mathrm{NE}(\Theta)$, 6 with $\mathrm{D}, \mathrm{L}-\left[{ }^{3} \mathrm{H}\right] \mathrm{NE}(\square)$, and 6 with $\mathrm{D}, \mathrm{L}-\left[{ }^{3} \mathrm{H}\right] \mathrm{E}(\mathrm{O})$. Means \pm SEM.

isolated kidney. When the perfusion apparatus was perfused without a kidney, $<10 \%$ of the $\left[{ }^{3} \mathrm{H}\right]$ catecholamine disappeared over a 70-min period.

The formation of metabolites by the isolated kidney is illustrated by the progressive fall in the percentage of total ${ }^{3} \mathrm{H}$ present as unmetabolized catecholamine
(Fig. 4). This percentage was smaller in urine than perfusion medium, indicating that catecholamine metabolites were concentrated in the urine. In both perfusion medium and urine, less $\mathrm{D}, \mathrm{L}-\left[{ }^{3} \mathrm{H}\right] \mathrm{E}$ was present as unchanged catecholamine than $L-\left[{ }^{3} \mathrm{H}\right] \mathrm{NE}$ a finding consistent with the higher metabolic clearance rate for D,L- $\left[{ }^{3} \mathrm{H}\right] \mathrm{E}$ as shown in Fig. 3.

The specific metabolites produced after $40 \mathrm{~min}$ of perfusion with $\left[{ }^{3} \mathrm{H}\right]$ catecholamine are shown in Table II; the values for perfusion medium and urine are from the last clearance period (between 30 and $40 \mathrm{~min}$ after the labeled amine was added). The kidney was removed after $\mathbf{4 0}$ min of perfusion and analyzed. The rate of appearance of the various metabolites is shown in Fig. 5. Significantly more $O$-methylated amine was formed from $D, L-\left[{ }^{3} \mathrm{H}\right] \mathrm{E}$ than from $\mathrm{L}-\left[{ }^{3} \mathrm{H}\right] \mathrm{NE}$. The formation of $O$-methylated amines was greater with racemic NE than with $\mathrm{L}-\left[{ }^{3} \mathrm{H}\right] \mathrm{NE}$.

The pattern of metabolites was identical after incubation of urine with and without Glusulase, a crude enzyme preparation containing $\beta$-glucuronidase and sulfatase. This indicates that significant amounts of glucuronide or sulfate conjugates were not formed by the isolated kidney.

Simultaneous perfusion of $D, L-\left[{ }^{14} C\right] E$ and $D, L-\left[{ }^{3} H\right] N E$ (Fig. 6). The data presented thus far, based on separate perfusions with each compound, indicate that $\mathrm{E}$ is excreted and metabolized more rapidly than NE. The simultaneous perfusion, therefore, of $\left[{ }^{14} \mathrm{C}\right] \mathrm{E}$ and $\left[{ }^{3} \mathrm{H}\right] \mathrm{NE}$ in equimolar concentrations should result in a progres-

TABLE II

Percentage of ${ }^{3} \mathrm{H}$

\begin{tabular}{|c|c|c|c|c|}
\hline & $\begin{array}{l}\text { Catecholamines } \\
\text { (unnetabolized) }\end{array}$ & $\begin{array}{l}\text { O-Methylated } \\
\text { amines }\end{array}$ & Catechol acids & $\begin{array}{c}O \text {-Methylated } \\
\text { deaminated }\end{array}$ \\
\hline \multicolumn{5}{|c|}{ Perfusion medium } \\
\hline L-[ $\left[{ }^{3} \mathrm{H}\right] \mathrm{NE}$ & $90.3 \pm 1.2$ & $1.3 \pm 0.6$ & $1.9 \pm 0.2$ & $6.7 \pm 1.6$ \\
\hline$D, L-\left[{ }^{3} \mathrm{H}\right] \mathrm{NE}$ & $92.5 \pm 1.6$ & $4.1 \pm 1.3$ & $1.0 \pm 0.3$ & $2.6 \pm 1.3$ \\
\hline $\mathrm{D}, \mathrm{L}-\left[{ }^{3} \mathrm{H}\right] \mathrm{E}$ & $77.0 \pm 1.6$ & $7.1 \pm 3.3$ & None detected & $15.5 \pm 2.9$ \\
\hline \multicolumn{5}{|l|}{ Urine } \\
\hline $\mathrm{L}-\left[{ }^{3} \mathrm{H}\right] \mathrm{NE}$ & $76.9 \pm 1.5$ & $11.4 \pm 1.3$ & $0.7 \pm 0.1$ & $10.9 \pm 1.5$ \\
\hline D,L- $\left[{ }^{3} \mathrm{H}\right] \mathrm{NE}$ & $72.8 \pm 2.2$ & $20.9 \pm 3.7$ & $0.3 \pm 0.1$ & $5.9 \pm 3.0$ \\
\hline $\mathrm{D}, \mathrm{L}-\left[{ }^{3} \mathrm{H}\right] \mathrm{E}$ & $49.6 \pm 4.5$ & $38.7 \pm 7.2$ & None detected & $11.7 \pm 3.5$ \\
\hline \multicolumn{5}{|l|}{ Kidney } \\
\hline L-[ $\left[{ }^{3} \mathrm{H}\right] \mathrm{NE}$ & $80.3 \pm 5.8$ & $8.9 \pm 2.0$ & $0.5 \pm 0.6$ & $10.4 \pm 4.2$ \\
\hline $\mathrm{D}, \mathrm{L}-\left[{ }^{3} \mathrm{H}\right] \mathrm{NE}$ & $82.1 \pm 1.2$ & $12.8 \pm 1.4$ & $0.1 \pm 0.04$ & $4.0 \pm 0.9$ \\
\hline D,L- $\left[{ }^{3} \mathrm{H}\right] \mathrm{E}$ & $42.3 \pm 9.0$ & $50.1 \pm 3.8$ & $0.07 \pm 0.05$ & $8.5 \pm 6.7$ \\
\hline
\end{tabular}

$\left[{ }^{3} \mathrm{H}\right]$ Catecholamines and $\left[{ }^{3} \mathrm{H}\right]$ metabolites in perfusion medium, urine, and kidney after $40 \mathrm{~min}$ of perfusion with either L- $\left[{ }^{3} \mathrm{H}\right] \mathrm{NE}, \mathrm{D}, \mathrm{L}-\left[{ }^{3} \mathrm{H}\right] \mathrm{NE}$, or L- $\left[{ }^{3} \mathrm{H}\right] \mathrm{E}$. Results are presented as percent of total ${ }^{3} \mathrm{H}$ in each metabolic fraction (means $\pm \mathrm{SEM}$ of five to six medium or urine samples and three to five kidneys). In perfusion medium, urine, and kidney the percentage of unchanged catecholamine was significantly less for $E$ than for either $D, L-\left[{ }^{3} H\right] N E$ or $L-\left[{ }^{3} H\right] N E(P<0.02)$. The percentage of $\left[{ }^{3} \mathrm{H}\right] \mathrm{O}$-methylated amine formed from $\mathrm{D}, \mathrm{L}-\left[{ }^{3} \mathrm{H}\right] \mathrm{E}$ was significantly greater in perfusion medium, urine, and kidney than the $\left[{ }^{3} \mathrm{H}\right] \mathrm{O}$-methylated amine formed from L- $\left[{ }^{3} \mathrm{H}\right] \mathrm{NE}$ but only in kidney was it significantly greater than that formed from $\mathrm{D}, \mathrm{L}-\left[^{3} \mathrm{H}\right] N E$. The percentage of $O$-methylated amine formed from $\mathrm{D}, \mathrm{L}-\left[{ }^{3} \mathrm{H}\right] \mathrm{NE}$ was significantly greater than that from the $\mathrm{L}$-isomer in urine $(P<0.05)$ but not in medium or kidney. 


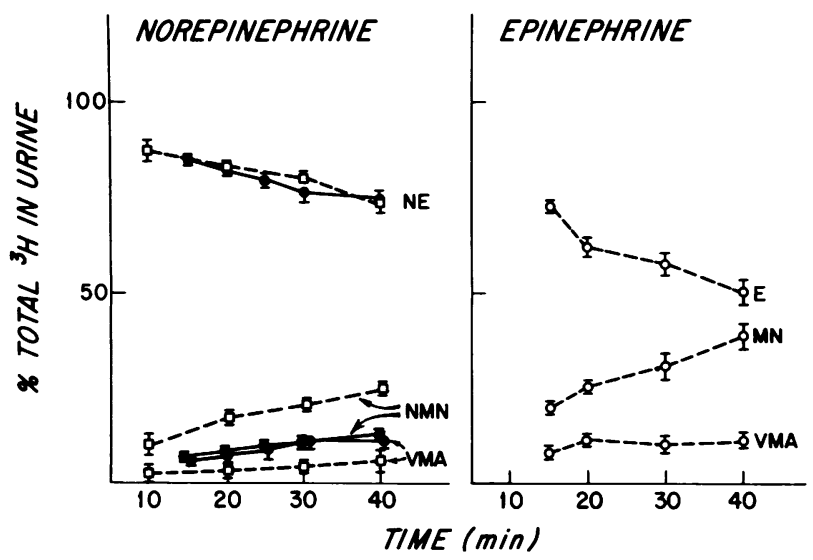

FIGURE 5 The appearance of $\left[{ }^{3} \mathrm{H}\right]$ catecholamine metabolites in urine. $\left[{ }^{3} \mathrm{H}\right]$ Catecholamine was added at time zero, and urine aliquots analyzed as shown in Fig. 2 and described in Methods. Results are means \pm SEM. Symbols as in Fig. 6. Note that catechol acids were not formed in significant quantities from either catecholamine. O-Methylated amine (NMN, MN) formed a significantly greater percentage of total ${ }^{3} \mathrm{H}$ in perfusions with $\mathrm{D}, \mathrm{L}-\left[{ }^{3} \mathrm{H}\right] \mathrm{E}$ and $\mathrm{D}, \mathrm{L}-\left[{ }^{3} \mathrm{H}\right] \mathrm{NE}$ than in perfusions with $\mathrm{L}-\left[{ }^{3} \mathrm{H}\right] \mathrm{NE}$ at equivalent media concentrations. Note that for $\mathrm{D}, \mathrm{L}-\left[{ }^{3} \mathrm{H}\right] \mathrm{NE}$ the increase in $\mathrm{O}$-methylated amines occurred at the expense of deaminated metabolites (VMA).

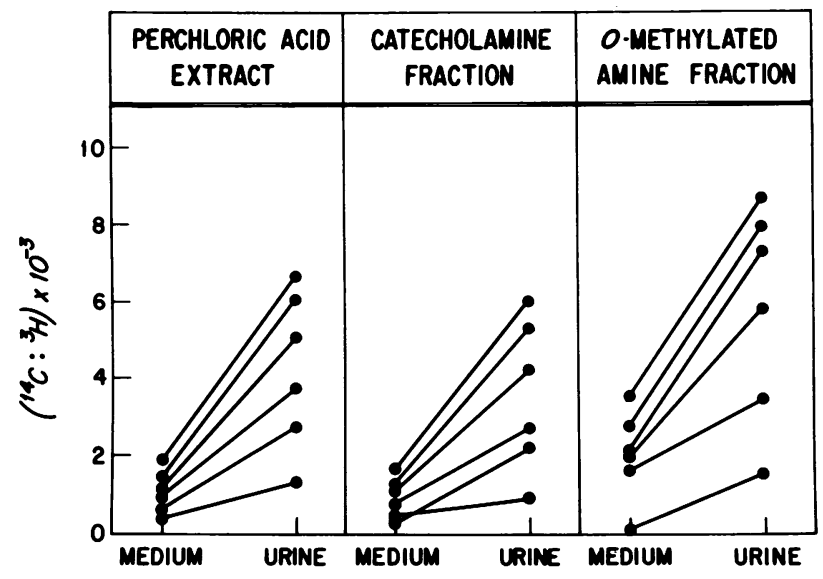

Figure $6{ }^{14} \mathrm{C}:{ }^{3} \mathrm{H}$ ratios in plasma and urine during kidney perfusion. D,L- $\left[{ }^{14} \mathrm{C}\right] \mathrm{E}(55.3 \mathrm{mCi} / \mathrm{mol})$ and $\mathrm{D}, \mathrm{L}-\left[{ }^{3} \mathrm{H}\right] \mathrm{NE}(7.5 \mathrm{Ci} /$ $\mathrm{mmol}$ ) were added to the bath in sufficient quantity to give an initial total medium concentration of $5 \mathrm{ng} / \mathrm{ml}$ of each amine. Urine was collected for three 15 -min periods and plasma sampled at the middle of each period. The ${ }^{14} \mathrm{C}:{ }^{3} \mathrm{H}$ ratio in perchloric acid extract, catecholamine fraction (alumina eluate) and $O$-methylated amine fraction (Dowex eluate) was determined as described in Methods. The ratios in corresponding urine and plasma samples are shown for two perfusions. At every point the ${ }^{14} \mathrm{C}:{ }^{3} \mathrm{H}$ ratio was greater in urine than in plasma. The ${ }^{14} \mathrm{C}:{ }^{3} \mathrm{H}$ ratio in simultaneously analyzed standards was not changed by the chromatographic separation techniques. In each perfusion the ${ }^{14} \mathrm{C}:{ }^{3} \mathrm{H}$ ratio in plasma fell continuously as the perfusion progressed. Addition of the same amount of $\left[{ }^{3} \mathrm{H}\right] \mathrm{NE}$ and $\left[{ }^{14} \mathrm{C}\right] \mathrm{E}$ to the perfusion apparatus without a kidney did not result in a significant change in the ratio after $\mathbf{4 0} \mathrm{min}$ of circulation, indicating that the results are not explained by volatilization of the ${ }^{3} \mathrm{H}$. sive fall of the ${ }^{14} \mathrm{C}:{ }^{3} \mathrm{H}$ ratio in the perfusion medium; furthermore the ${ }^{14} \mathrm{C}:{ }^{3} \mathrm{H}$ ratio in urine should exceed the corresponding ${ }^{14} \mathrm{C}:{ }^{3} \mathrm{H}$ ratio in the perfusion medium at all times during the experiment. This is borne out by results shown in Fig. 6 . The ${ }^{14} \mathrm{C}:{ }^{3} \mathrm{H}$ ratio in urine exceeded that in perfusion medium in all the study periods. This was true for total radioactivity, the catecholamine fraction, and in the $\mathrm{O}$-methylated amine fraction, indicating increased excretion of $E$ and increased conversion to the $O$-methylated amine metabolite (metanephrine). The ${ }^{14} \mathrm{C}:{ }^{3} \mathrm{H}$ ratio in the perfusion medium fell progressively from start to finish in both perfusions. The results confirm that $\mathrm{E}$ is excreted and $O$-methylated more rapidly than NE.

\section{DISCUSSION}

The studies reported here provide strong evidence in favor of net tubular secretion of both $E$ and NE. Inasmuch as the amount of catecholamine appearing in the urine exceeded the filtered load, net secretion must have occurred. It should be noted that the calculation of the filtered load depends on the free catecholamine concentration; for substances bound to plasma proteins or, in the case of the isolated perfused kidney, the albumin in the perfusate, an accurate estimate of protein binding is essential. For example, uncorrected for albumin binding, the fractional excretion of $\mathrm{NE}$ is $<1$ in the studies reported here $(\cong 0.64)$. This is very similar to the value obtained by Overy et al. (7) for $\mathrm{NE}$ clearance in the anesthetized dog. In that study, the authors found no evidence of protein binding in three experiments using a collodion sac which they centrifuged for $30 \mathrm{~min}$. Consequently, they used the total plasma concentration in the clearance calculations and concluded that NE was excreted by glomerular filtration. This conclusion is in disagreement with several other reported studies which, like the present work, found evidence for net tubular secretion (2-5). In the studies reported here, evidence of protein binding was consistently found, and the free fraction was used in calculating filtered load. These binding experiments, which were carefully performed and repeated many times (with each new experiment), indicated that only $30 \%$ of $\left[{ }^{3} \mathrm{H}\right]$ catecholamine was freely permeable across cellophane membranes. Other studies also support binding of catecholamines to protein $(6,22-25)$, and it seems likely that the failure of Overy et al. (7) to demonstrate net tubular secretion for NE resulted from the failure to detect significant protein binding in their preparation. Furthermore, it should be noted that in the present studies the fractional excretion of $D, L-\left[{ }^{3} \mathrm{H}\right] \mathrm{E}$ and $\mathrm{D}, \mathrm{L}-\left[{ }^{3} \mathrm{H}\right] \mathrm{NE}$ exceeded unity even without a correction for protein binding, thereby confirming net tubular secretion. 
The secretion of $\mathrm{E}$ and NE (Fig. 3) was a linear function of the concentration of free catecholamine in the medium. No tubular maximum secretory rate was demonstrated at the concentrations studied $(0.2-5 \mathrm{ng} / \mathrm{ml}$ unbound); higher concentrations are difficult to study because of the vascular effects they introduce. The levels studied here are slightly higher than the usual levels in human blood, where the total catecholamine concentration is under $1 \mathrm{ng} / \mathrm{ml}$ and about $50 \%$ of that is bound. Over the 25-fold range in perfusate concentration studied, however, there was no difference in fractional excretion or in the pattern of metabolites produced. The direct relationship between perfusate concentration and catecholamine secretion seen in these studies, if extrapolated to intact animals, suggests that urinary catechölamine excretion might be a valid, integrated guide to plasma levels of catecholamines.

In addition to excretion of unmetabolized catecholamine by filtration and tubular secretion, the isolated kidney displayed a substantial capacity to metabolize $\mathrm{E}$ and NE. As shown in Fig. 3, $\cong 33 \%$ of the NE removed from the medium can be accounted for by metabolism, whereas $50 \%$ of the $\mathrm{E}$ is removed by metabolic transformation. The significant increase in $\mathrm{E}$ metabolism as compared with NE (Figs. 3 and 4; Table II) cannot be explained by the use of $\mathrm{D}, \mathrm{L}-\left[{ }^{3} \mathrm{H}\right] \mathrm{E}$ in these experiments. When compared with $\mathrm{D}, \mathrm{L}-\left[{ }^{3} \mathrm{H}\right] \mathrm{NE}$, the rate of removal from perfusate (Fig. 3), as well as the amount of metabolites formed, was significantly greater for $\mathrm{E}$. Comparison of the metabolic pattern for $\mathrm{D}, \mathrm{L}-$ and L- $\left[{ }^{3} \mathrm{H}\right] \mathrm{NE}$ (Fig. 5; Table I) does reveal a significant difference in the metabolic fate of $L$ - and $D, L-\left[{ }^{3} \mathrm{H}\right] \mathrm{NE}$, with significantly more $O$-methylated amine formed from the racemic NE. The overall metabolic clearance of D,L- and L- $\left[{ }^{3} \mathrm{H}\right] \mathrm{NE}$ did not differ however, (Fig. 3) and the increase in $\mathrm{O}$-methylated amines formed from D,L- $\left[{ }^{3} \mathrm{H}\right] \mathrm{NE}$ was associated with a corresponding fall in the $\mathrm{O}$-methylated-deaminated metabolites (VMA) (Fig. 4; Table II). It appears likely that the increase in methylated amine formation from $D, L-\left[{ }^{3} \mathrm{H}\right] \mathrm{NE}$ reflects the preference of monoamine oxidase for the naturally occurring L-isomer $(26,27)$ since catechol- $O$-methyltransferase does not display stereospecificity $(26,28)$. The formation of methanephrine from $D, L-\left[{ }^{3} \mathrm{H}\right] \mathrm{E}$ may also have been increased at the expense of VMA by the stereospecificity of monoamine oxidase (Fig. 5; Table I).

The experiments reported here indicate that the isolated rat kidney both secretes and metabolizes $\mathrm{E}$ more avidly than NE (Figs. 1-5, Table II). The preferential excretion and metabolism of $\mathrm{E}$ was confirmed in the double-label experiments shown in Fig. 6. The simultaneous perfusion of $\mathrm{D}, \mathrm{L}-\left[{ }^{14} \mathrm{C}\right] \mathrm{E}$ and $\mathrm{D}, \mathrm{L}-\left[{ }^{3} \mathrm{H}\right] \mathrm{NE}$ was associated with significant enhancement of the ${ }^{14} \mathrm{C}:{ }^{3} \mathrm{H}$ ratio in urine as compared with perfusion medium. This was true for the catecholamine fraction and the $\mathrm{O}$-methylated amine fraction. The corresponding ratio in the kidney perfusate fell progressively during the perfusion. The preferential secretion and metabolism of $\mathrm{E}$ as compared with $\mathrm{NE}$ can best be explained by an increased affinity of the renal tubular cell for $E$. Accumulation of catecholamines in the renal epithelium must precede both secretion and metabolism, and more avid uptake of $\mathrm{E}$ would account for an increase in both events.

These experiments thus demonstrate that catecholamines are both secreted and metabolized by the mammalian kidney. The data suggest that urinary excretion might serve as a guide to plasma levels of catechols integrated over time, and raise the possibility that a diminution in renal function or renal mass may substantially alter the metabolism and disposition of catecholamines by the body.

\section{ACKNOWLEDGMENTS}

The authors are grateful to Martha B. Berardino, Kate Spokes, Diana Kuchmy, and Michael Mishkind for excellent technical assistance; to Patti Fiorenza for preparation of the manuscript; and to Dr. F. H. Epstein for his helpful suggestions and careful review of the manuscript.

This work was supported in part by the Charles A. King Trust, National Institutes of Health grants AM07199, HL 11414, 9R01 AM 180 78, AM 20378, and RR76.

\section{REFERENCES}

1. Weiner, I. M. 1973. Transport of weak acids and bases. 8: 521-554.

2. Rennick, B. R., and N. Yoss. 1962. Renal tubular excretion of DL-epinephrine-2-C ${ }^{14}$ in the chicken. Am. J. Physiol. 215: 347-350.

3. Quebbemann, A., and B. Rennick. 1970. Inhibition of renal tubular transport of catecholamines by cocaine: an organic base mechanism. J. Pharmacol. Exp. Ther. 175: 248-258.

4. Rennick, B., and A. Quebbemann. 1970. Site of excretion of catechol and catecholamines: renal metabolism of catechol. Am. J. Physiol. 218: 1307-1312.

5. Jones, R. T. 1958. Renal excretion of L-epinephrine in the dog. Am. J. Physiol. 215: 371-374.

6. Rennick, B. R. 1968. Dopamine: renal tubular transport in the dog and plasma binding studies. Am. J. Physiol. 215: $532-534$.

7. Overy, H. R., R. Pfister, and C. A. Chidsey. 1967. Studies on the renal excretion of norepinephrine. J. Clin. Invest. 46: $482-489$.

8. Nagatsu, T., L. A. Rust, and V. DeQuattro. 1969. The activity of tyrosine hydroxylase and related enzymes of catecholamine biosynthesis and metabolism in dog kidney - the effects of denervation. Biochem. Pharmacol. 18: $1441-1446$.

9. Rennick, B. R., M. Z. Pryor, and B. G. Basch. 1965. Urinary metabolites of epinephrine and norepinephrine in the chicken. J. Pharmacol. Exp. Ther. 148: 270-276.

10. Whitby, L. G., J. Axelrod, and H. Weil-Malherbe. 1961. The fate of ${ }^{3} \mathrm{H}$-norepinephrine in animals. J. Pharmacol. Exp. Ther. 132: 193-201.

11. Nishiitsutsuji-Uwo, J. M., B. D. Ross, and H. A. Krebs. 1967. Metabolic activities of the isolated perfused rat kidney. Biochem. J. 103: 852-862. 
12. Ross, B. D., F. H. Epstein, and A. Leaf. 1973. Sodium reabsorption in the perfused rat kidney. Am. J. Physiol. 225: 1165-1171.

13. Ross, B., A. Leaf, P. Silva, and F. H. Epstein. 1974. Na-KATPase in sodium transport by the perfused rat kidney. Am. J. Physiol. 226: 624-629.

14. White, R. P., and F. E. Samson, Jr. 1954. Determination of inulin in plasma and urine by use of anthrone. J. Lab. Clin. Med. 43: 475-478.

15. Landsberg, L., M. B. Berardino, and P. Silva. 1974. Metabolism of ${ }^{3} \mathrm{H}-\mathrm{L}$-dopa by the rat gut in vivo-evidence for glucuronide conjugation. Biochem. Pharmacol. 24: 1167-1174.

16. Anton, A. H., and D. R. Sayre. 1962. A study of the factors affecting the aluminum oxide trihydroxyindole procedure for the analysis of catecholamines. J. Pharmacol. Exp. Ther. 139: 360-375.

17. Hirs, C. H. W., S. Moore, and W. H. Stein. 1953. A chromatographic investigation of pancreatic ribonuclease. J. Biol. Chem. 200: 493-506.

18. Kopin, I. J., J. Axelrod, and E. Gordon. 1961. The metabolic fate of $\mathrm{H}^{3}$-epinephrine and $\mathrm{C}^{14}$-methanephrine in the rat. J. Biol. Chem. 236: 2109-2133.

19. Eisenfeld, A. J., J. Axelrod, and L. Krakoff. 1967. Inhibition of the extraneuronal accumulation and metabolism of norepinephrine by adrenergic blocking agents.J. Pharmacol. Exp. Ther. 156: 107-113.

20. Tyce, G. M., N. S. Sharpless, and C. A. Owen, Jr. 1972.
Isolation of metabolites of L-dopa-a possible source of error. Biochem. Pharmacol. 21: 2409-2412.

21. Toribara, T. Y., A. R. Terepka, and P. A. Dewey. 1957. The ultrafiltrable calcium of human serum. I. Ultrafiltration methods and normal values. J. Clin. Invest. 36: 738-748.

22. Danon, A., and J. D. Sapira. 1972. Binding of catecholamines to human serum albumin.J. Pharmacol. Exp. Ther. 182: 295-302.

23. Collier, J. G. 1972. New dialysis technique for the continuous measurement of the concentration of vaso-active hormones. Br. J. Pharmacol. 44: 383P.

24. May, P., F. H. Sanders, and R. K. Donabedian. 1974. Binding of catechol derivatives to human serum proteins. Experientia (Basel). 30: 304-305.

25. Powis, G. 1975. The binding of catecholamines to human serum proteins. Biochem. Pharmacol. 24: 707-712.

26. Iversen, L. L., B. Jarrott, and M. A. Simmonds. 1971. Differences in the uptake, storage and metabolism of $(+)$ - and (-) - noradrenaline. Br. J. Pharmacol. 43: 845855.

27. Levin, J. A. 1974. The uptake and metabolism of ${ }^{3} \mathrm{H}-\mathrm{L}$ and ${ }^{3} \mathrm{H}-\mathrm{DL}-$ norepinephrine by intact rabbit aorta and by isolated adventitia and media. J. Pharmacol. Exp. Ther. 190: 210-226.

28. Axelrod, J., and R. Tomchick. 1958. Enzymatic $O$-methylation of epinephrine and other catechols. J. Biol. Chem. 233: 702-705. 